\title{
PEMANFAATAN Spirulina platensis UNTUK MENINGKATKAN KINERJA PERTUMBUHAN DAN KETAHANAN TUBUH IKAN ZEBRA (Danio rerio)
}

\author{
(Utilization of Spirulina platensis to Enhance Growth Performance and Immunity \\ of Zebrafish (Danio rerio)
}

\author{
Lukman Anugrah Agung ${ }^{1}$, Muh. Herjayanto ${ }^{2}$, Eltis Panca Ningsih ${ }^{3}$, Edo Ahmad \\ Solahudin $^{4}$, Esa Rama Widiyawan ${ }^{5}$ \\ 1,2,4,5 Program Studi Ilmu Perikanan, Universitas Sultan Ageng Tirtayasa \\ Penulis koresponden: ${ }^{1}$ lukman.anugrah@untirta.ac.id, \\ ${ }^{2}$ herjayanto@untirta.ac.id, ${ }^{4}$ edo2609solahudin@gmail.com, ${ }^{5}$ ramaesa16@gmail.com \\ ${ }^{3}$ Program Studi Agroekoteknologi, Universitas Sultan Ageng Tirtayasa \\ Email : ${ }^{3}$ eltispn14@untirta.ac.id \\ Jalan Raya Jakarta KM4, Pakupatan, Serang, Banten
}

Article Submitted: 25-02-2021

Article Accepted: 24-05-2021

\begin{abstract}
The purpose of this research was to evaluate the effect of different concentrations of Spirulina platensis supplementation on artificial feed for zebrafish (Danio rerio) to increase growth performance and immunity from environmental pressure. The experimental research was carried out from October 2020 until November 2020 at Aquaculture Laboratory, University of Sultan Ageng Tirtayasa, Serang, Banten. This research used a complete randomized design (CRD) consisted of 4 treatments and 3 replications. Control was commercial pellet which no $S$. platensis enriched (A), pellet enriched with $3 \%$ of S. platensis (B), pellet enriched with $6 \%$ of $S$. platensis (C), and last treatment was pellet enriched with $9 \%$ of $S$. platensis (D). The results showed that treatment C was the best dosage of S. platensis for zebrafish rearing for 40 days both growth and immunity performance. Absolute length, specific growth rate of length, absolute weight, specific growth rate of weight were significantly different, but the survival rate was not significantly different which were $0.646 \pm 0.112 \mathrm{~cm}, \quad 0.714 \pm 0.10 \%, \quad 0.102 \pm 0.020 \mathrm{~g}$, $1.422 \pm 0.215 \%, 100 \%$ respectively. Immunity performance was shown by the stress test at low $\mathrm{pH}$. It was also significantly different when exposed to $\mathrm{pH}$ at $5 \mathrm{ppt}$ among the treatment. Treatment $\mathrm{C}$ was the highest survival rate which was $63.33 \pm 5.77 \%$ after the stress test at low $\mathrm{pH}$.
\end{abstract}

Keywords: S. platensis, growth performance, survival rate, Immunity

\section{PENDAHULUAN}

Ikan hias merupakan salah satu komoditas perikanan budidaya yang potensial untuk dikembangkan. Salah satu ikan hias yang sering dibudidayakan oleh masyarakat adalah ikan zebra (Danio rerio). Upaya untuk meningkatkan produktivitas ikan zebra telah dilakukan diantaranya dengan penggunaan pakan yang sesuai dengan kebutuhan nutrisi ikan zebra (Karga dan Mandal, 2016). Namun, terdapat kendala dalam budidaya ikan zebra diantaranya yaitu serangan penyakit yang dapat diakibatkan oleh parasit, jamur, bakteri dan virus (Rowe et al. 2014). Menurut Kabata (1985), kejadian penyakit pada ikan disebabkan oleh interaksi inang, patogen dan lingkungan yang kurang optimal yang mengakibatkan ikan stres sehingga menurunkan ketahanan tubuh ikan terhadap penyakit. Stres juga akan 
mengakibatkan lambatnya pertumbuhan ikan dan kematian ikan sehingga menimbulkan kerugian pada budidaya ikan zebra. Oleh karena itu, diperlukan suplementasi bahan bersifat imunostimulan yang dapat meningkatkan ketahanan tubuh ikan saat kondisi stres akibat tekanan lingkungan sehingga dapat meningkatkan kelangsungan hidup ikan. Salah satu bahan imunostimulan yang dapat diaplikasikan adalah Spirulina platensis.

S. platensis merupakan mikroalga hijau-biru yang banyak dibudidayakan secara komersial. S. platensis memiliki kandungan nutrisi yang lengkap yang diharapkan mampu meningkatkan pertumbuhan ikan diantaranya yaitu protein, tokoferol, asam amino esensial, mineral serta asam lemak esensial (Takeuchi et al. 2002). Nazhiroh et al. (2019) melaporkan bahwa suplementasi $S$. platensis dalam pakan dapat meningkatkan pertumbuhan dan efisiensi pakan pada ikan maskoki (Carassius auratus). Selain itu, S. platensis memiliki kandungan antioksidan yang mampu meningkatkan glutation peroksidase, enzim katalase serta menurunkan MDA (malondialdehyd) sehingga berpotensi untuk menurunkan tingkat stres pada ikan akibat tekanan lingkungan. Hasil penelitian Abdelkhalek et al. (2015) menunjukkan bahwa $S$. platensis memiliki aktivitas antioksidan yang tinggi sehingga mampu menurunkan tingkat stres ikan nila akibat tekanan lingkungan yang diberikan. $\mathrm{pH}$ merupakan pembatas dalam budidaya ikan hias, karena $\mathrm{pH}$ yang rendah akan menyebabkan toksisitas amoniak meningkat sehingga daya tahan tubuh ikan akan menurun. Berdasarkan urairan diatas perlu dilakukan penelitian mengenai penggunaan $S$. platensis untuk meningkatkan kinerja pertumbuhan dan kelangsungan hidup ikan zebra pada cekaman lingkungan $\mathrm{pH}$ rendah.

\section{METODE PENELITIAN}

\section{Waktu dan Tempat}

Penelitian ini dilakukan selama 40 hari, pada bulan Oktober-November 2020. Penelitian dilaksanakan di Laboratorium Budidaya Perairan, Program Studi Ilmu Perikanan, Fakultas Pertanian, Universitas Sultan Ageng Tirtayasa.

\section{Rancangan penelitian}

Penelitian ini menggunakan rancangan acak lengkap (RAL) dengan 4 perlakuan dan 3 ulangan. Perlakuan yang dilakukan pada penelitian ini yaitu pemberian pakan yang telah diberi $S$. platensis dengan dosis sebagai berikut :

Perlakuan A : Tanpa pemberian $S$. platensis (Kontrol)

Perlakuan B : Pemberian S. platensis dengan dosis $3 \%$

Perlakuan C : Pemberian $S$. platensis dengan dosis $6 \%$

Perlakuan D : Pemberian S. platensis dengan dosis $9 \%$

\section{Prosedur penelitian \\ Persiapan wadah}

Wadah pemeliharaan yang digunakan dalam penelitian ini yaitu akuarium dengan ukuran 30x30x30 cm sebanyak 12 unit. Akuarium dicuci dengan air bersih terlebih dahulu sebelum digunakan, kemudian dilakukan pengeringan di bawah sinar matahari. Akuarium selanjutnya diisi air sampai ketinggian 15 $\mathrm{cm}$, kemudian ditambahkan aerasi untuk setiap akuarium.

\section{Persiapan pakan uji}

Pakan uji yang digunakan dalam penelitian ini merupakan pakan komersial dengan kandungan protein $40 \%$ yang dicampur dengan tepung $S$. platensis komersial dengan dosis sesuai dengan perlakuan. Pembuatan pakan dengan menggunakan metode coating. Tepung $S$. platensis dengan dosis sesuai perlakuan ditempatkan dalam sprayer, kemudia ditambahkan $100 \mathrm{~mL}$ air. Selanjutnya, larutan S. platensis tersebut disemprotkan ke atas pelet yang sudah ditempatkan dalam wadah plastik sambil diaduk perlahan 
hingga merata. Pakan uji tersebut dikeringanginkan, kemudian disimpan dalam wadah yang ditutup rapat sebelum digunakan.

\section{Penebaran benih dan pemeliharaan ikan uji}

Benih yang digunakan adalah ikan zebra dengan bobot $0.134 \pm 0.001 \mathrm{~g}$. Penebaran benih dilakukan dengan padat tebar 1 ekor. $\mathrm{L}^{-1}$ sehingga setiap akuarium berisi 15 ekor ikan. Sebelum diberi perlakuan, benih ikan zebra terlebih dahulu diaklimatisasi selama 3 hari untuk menyesuaikan kondisi lingkungan.
Pemberian pakan dilakukan dengan cara at satiation dan diberikan pada pagi hari, siang hari, dan sore hari. Pemeliharaan ikan dilakukan selama 40 hari, kemudian dilakukan uji ketahanan tubuh ikan zebra terhadap stres dengan paparan $\mathrm{pH}$ rendah. Nilai $\mathrm{pH}$ yang digunakan yaitu $5 \pm 0.1$.

\section{Pengelolaan kualitas air}

Kualitas air pada wadah pemeliharaan yang digunakan pada penelitian ini tersaji pada tabel 2. Kualitas air yang digunakan pada pemeliharaan ikan zebra selama 40 hari masih berada pada kisaran normal.

Tabel 2. Kualitas air pada media pemeliharaan ikan zebra

\begin{tabular}{lllll}
\hline \multirow{2}{*}{ Parameter } & \multicolumn{4}{c}{ Perlakuan } \\
\cline { 2 - 5 } \multicolumn{1}{c}{ A } & \multicolumn{1}{c}{ B } & \multicolumn{1}{c}{$\mathrm{C}$} & \multicolumn{1}{c}{ D } \\
\hline Suhu $\left({ }^{\circ} \mathrm{C}\right)$ & $26,6-27,2$ & $25,7-26,4$ & $26,5-27,3$ & $26,3-27.0$ \\
pH & $6.9-7.1$ & $6.8-7,0$ & $6.8-7.2$ & $6.9-7.3$ \\
DO $\left(\mathrm{mg} . \mathrm{L}^{-1}\right)$ & $5.8-6.1$ & $5.9-6.1$ & $6,0-6.2$ & $5.8-6.3$ \\
Amoniak $\left(\mathrm{mg} . \mathrm{L}^{-1}\right)$ & $0,02-0,20$ & $0,02-0,20$ & $0,10-0,30$ & $0,10-0,30$ \\
\hline
\end{tabular}

\section{Parameter penelitian}

Parameter yang diamati pada penelitian ini meliputi pertumbuhan panjang mutlak, laju pertumbuhan spesifik panjang, pertumbuhan bobot mutlak, laju pertumbuhan spesifik bobot, kelangsungan hidup ikan zebra setelah pemberian $S$. platensis selama 40 hari, dan kelangsungan hidup ikan setelah paparan $\mathrm{pH}$ rendah.

\section{Analisis Data}

Hasil data yang diperoleh dari setiap pengukuran parameter penelitian ditabulasikan dalam program Microsoft excel 2013 untuk disajikan dalam tabel dan grafik. Kemudian dianalisis secara statistik menggunakan uji sidik ragam (ANOVA) dengan selang kepercayaan 95\%. Jika hasil yang diperoleh berbeda nyata $(\mathrm{P}<0,05)$, dilakukan uji jarak berganda Duncan menggunakan perangkat lunak komputer SPSS versi 26.

\section{HASIL DAN PEMBAHASAN}

\section{Kinerja Pertumbuhan Ikan Zebra}

Kinerja pertumbuhan ikan zebra yang diamati pada penelitian ini meliputi pertumbuhan panjang mutlak, laju pertumbuhan spesifik panjang, pertumbuhan bobot mutlak, dan laju pertumbuhan spesifik bobot. Hasil penelitian selama 40 hari menunjukkan bahwa ikan zebra mengalami pertumbuhan yang berbeda. Hasil pertumbuhan panjang mutlak, laju pertumbuhan spesifik panjang, pertumbuhan bobot mutlak, laju pertumbuhan spesifik bobot, kelangsungan hidup pada hari ke-40 serta kelangsungan ikan zebra setelah paparan $\mathrm{pH}$ rendah tersaji pada tabel 1. 
Tabel 1. Pertumbuhan panjang mutlak, laju pertumbuhan spesifik panjang, pertumbuhan bobot mutlak, laju pertumbuhan spesifik bobot, kelangsungan hidup pada hari ke-40 serta kelangsungan ikan zebra setelah paparan $\mathrm{pH}$ rendah

\begin{tabular}{|c|c|c|c|c|}
\hline \multirow[t]{2}{*}{ Parameter } & \multicolumn{4}{|c|}{ Perlakuan pemberian S. platensis } \\
\hline & $\mathrm{A}(0 \%)$ & $\mathrm{B}(3 \%)$ & $\mathrm{C}(6 \%)$ & $\mathrm{D}(9 \%)$ \\
\hline Pertumbuhan & $0.436 \pm 0.0301^{\mathrm{a}}$ & $0.612 \pm 0.0464^{b}$ & $0.646 \pm 0.112^{b}$ & $0.564 \pm 0.040^{b}$ \\
\hline $\begin{array}{l}\text { Panjang mutlak } \\
(\mathrm{cm})\end{array}$ & & & & \\
\hline $\begin{array}{l}\text { Laju pertumbuhan } \\
\text { spesifik panjang } \\
(\%)\end{array}$ & $0.505 \pm 0.032^{\mathrm{a}}$ & $0.682 \pm 0.045^{b}$ & $0.714 \pm 0.107^{\mathrm{b}}$ & $0.635 \pm 0.039^{b}$ \\
\hline $\begin{array}{l}\text { Pertumbuhan bobot } \\
\text { mutlak (g) }\end{array}$ & $0.067 \pm 0.003^{\mathrm{a}}$ & $0.096 \pm 0.008^{b}$ & $0.102 \pm 0.020^{b}$ & $0.081 \pm 0.016^{\mathrm{ab}}$ \\
\hline $\begin{array}{l}\text { Laju pertumbuhan } \\
\text { spesifik bobot }(\%)\end{array}$ & $1.025 \pm 0.033^{\mathrm{a}}$ & $1.359 \pm 0.09^{b}$ & $1.422 \pm 0.215^{\mathrm{b}}$ & $1.186 \pm 0.172^{\mathrm{ab}}$ \\
\hline $\begin{array}{l}\text { Kelangsungan } \\
\text { hidup pada hari ke- } \\
40(\%)\end{array}$ & $100 \pm 0^{\mathrm{a}}$ & $100 \pm 0^{\mathrm{a}}$ & $100 \pm 0^{\mathrm{a}}$ & $100 \pm 0^{\mathrm{a}}$ \\
\hline 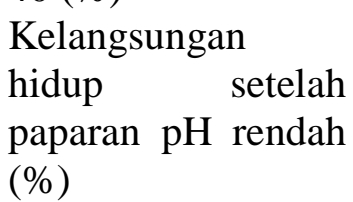 & $36.67 \pm 11.55^{\mathrm{a}}$ & $60.00 \pm 10.00^{b}$ & $63.33 \pm 5.77^{b}$ & $46.67 \pm 5.77^{\mathrm{ab}}$ \\
\hline
\end{tabular}

Keterangan : Nilai rerata dengan superskrip yang sama pada baris yang sama menunjukkan nilai yang tidak berbeda nyata $(\mathrm{P}>0,05)$.

Hasil pertumbuhan panjang mutlak dan laju pertumbuhan spesifik panjang ikan zebra yang diberi S. platensis melalui pakan menunjukkan hasil yang bervariasi pada setiap perlakuan. Perlakuan $\mathrm{C}$ menunjukkan perlakuan pertumbuhan panjang mutlak yang tertinggi yaitu sebesar $0.646 \pm 0.112$ $\mathrm{cm}$, sedangkan perlakuan A menunjukkan panjang mutlak yang terendah sebesar $0.436 \pm 0.0301 \mathrm{~cm}$. Hasil analisa sidik ragam menunjukkan bahwa pemberian $S$. platensis melalui pakan selama 40 hari pada perlakuan B (3\%), C (6\%), dan D (9\%) menghasilkan pertumbuhan panjang mutlak ikan zebra yang berbeda nyata $(\mathrm{P}<0.05)$ dengan perlakuan $\mathrm{A}(0 \%)$.

Hasil laju pertumbuhan spesifik panjang ikan zebra menunjukkan pola yang sama dengan pertumbuhan panjang mutlak. Laju pertumbuhan spesifik panjang yang tertinggi yaitu pada perlakuan $\mathrm{C}$ dengan nilai $0.714 \pm 0.107 \%$ yang berbeda nyata $(\mathrm{P}<0.05)$ dengan perlakuan $\mathrm{A}$ namun tidak berbeda nyata dengan perlakuan B dan D. Hasil tersebut menunjukkan bahwa ikan zebra dapat memanfaatkan $S$. platensis sebagai sumber nutrisi dan energi selama pemeliharaan sehingga meningkatkan efisiensi pemanfaatan pakan yang ditunjukkan dengan pertumbuhan panjang mutlak dan laju pertumbuhan panjang yang optimal. Sejalan dengan penelitian ini, Kim et al. (2013) mengemukaan bahwa $S$. platensis mengandung sumber nutrisi dan sumber energi yang baik bagi hewan termasuk ikan sehingga dapat menunjang efisiensi pemanfaatan pakan. Lebih lanjut, Bahmai et al. (2017) menjelaskan bahwa $S$. platensis memiliki kandungan protein, vitamin, asam amino dan asam lemak yang tinggi sehingga berperan dalam meningkatkan pertumbuhan pada ikan zebra. Hasil penelitian menunjukkan bahwa pertumbuhan bobot mutlak pada ikan zebra yang diberi $S$. platensis melalui pakan selama 40 hari pemeliharaan menunjukkan 
peningkatan apabila dibandingkan dengan kontrol (A). Perlakuan C (6\%) dengan nilai $0.102 \pm 0.020 \mathrm{~g}$ menunjukkan pertumbuhan bobot mutlak ikan zebra tertinggi yang berbeda nyata $(\mathrm{P}<0.05)$ dengan perlakuan $\mathrm{A}$ (0\%) namun tidak berbeda nyata dengan perlakuan B (3\%) dan D (9\%) dengan nilai secara berurutan yaitu $0.067 \pm 0.003 \mathrm{~g}$, $0.096 \pm 0.008 \mathrm{~g}$ dan $0.081 \pm 0.016 \mathrm{~g}$. Pada tabel 1 dapat dilihat bahwa laju pertumbuhan spesifik bobot ikan zebra mengalami peningkatan pada perlakuan A hingga perlakuan $\mathrm{C}$, kemudian mengalami penurunan pada perlakuan D. Perlakuan C menunjukkan laju pertumbuhan spesifik bobot ikan zebra yang tertinggi dengan nilai $1.422 \pm 0.215 \%$ yang berbeda nyata dengan perlakuan A senilai $1.025 \pm 0.033 \%$ namun tidak berbeda nyata dengan perlakuan B dengan nilai $1.359 \pm 0.09 \%$ dan $\mathrm{D}$ dengan nilai $1.186 \pm 0.172 \%$.

Menurut Dani et al. (2005), pertumbuhan pada ikan dipengaruhi oleh umur dan ukuran ikan, kualitas dan kuantitas pakan, padat tebar ikan, jumlah pakan, frekuensi permberian pakan, serta perbedaan komposisi nutrisi bahan pakan ikan. Selanjutnya, Kusumaningrum et al. (2014) mengemukakan bahwa protein merupakan bahan baku utama pembentukan sel dan jaringan tubuh sehingga pertumbuhan ikan sangat tergantung pada kandungan protein dan komposisi asam amino yang seimbang pada pakan. Menurut
Nur et al. (2014), S. platensis kering memiliki kandungan protein mencapai $65 \%$ dan kandungan vitamin yang tinggi. Laju pertumbuhan spesifik bobot ikan zebra pada perlakuan $\mathrm{D}$ tidak menunjukkan perbedaan yang nyata $(\mathrm{P}>0.05)$ dengan perlakuan $\mathrm{A}$. Hasil ini diduga terkait dengan tingginya kandungan serat kasar pada pemberian $S$. platensis dosis tertinggi pada perlakuan D sehingga menurunkan efisiensi pemanfaatan pakan ikan. Hasil penelitian El-Sheekh et al. (2017) memperlihatkan hal serupa bahwa pemberian S. platensis sampai taraf $100 \%$ melalui pakan untuk menggantikan tepung ikan ternyata menunjukkan pertumbuhan bobot mutlak dan laju pertumbuhan bobot yang lebih rendah apabila dibandingkan dengan pemberian $S$. platensis pada taraf 75\%. Menurut Virnanto et al. (2016), tingginya serat kasar dan energi mengakibatkan penurunan jumlah konsumsi pakan karena ikan akan cepat merasa kenyang sehingga dapat menurunkan penyerapan protein dan asam amino dari pakan yang selanjutnya akan menunjukkan pertumbuhan yang menurun.

\section{Ketahanan ikan zebra terhadap stres}

Ketahanan ikan zebra terhadap stres akibat paparan pada $\mathrm{pH}$ rendah dievaluasi dari kelangsungan hidup ikan setelah paparan $\mathrm{pH}$ rendah. Hasil kelangsungan hidup ikan zebra setelah paparan $\mathrm{pH}$ rendah tersaji pada gambar 2 . 


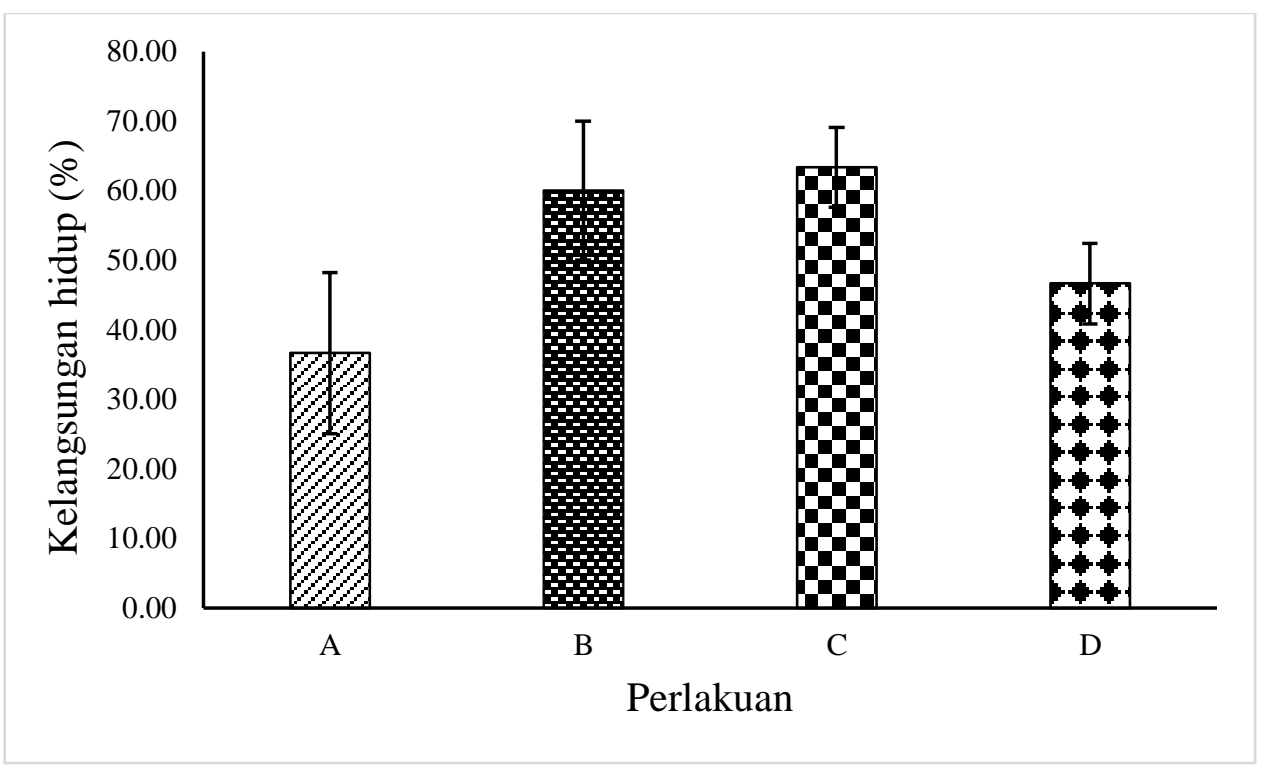

Gambar 2. Kelangsungan hidup ikan zebra setelah paparan $\mathrm{pH}$ rendah

Hasil penelitian menunjukkan bahwa pemberian $S$. platensis melalui pakan memberikan kontribusi dalam meningkatkan kelangsungan hidup ikan zebra yang dipaparkan pada $\mathrm{pH}$ rendah. Kelangsungan hidup tertinggi ditunjukkan oleh perlakuan $\mathrm{C}$ senilai $\quad 63.33 \pm 5.77 \% \quad$ sedangkan kelangsungan hidup terendah yaitu pada perlakuan A senilai $36.67 \pm 11.55 \%$. Hasil analisa ragam menunjukkan bahwa pemberian $S$. platensis pada perlakuan B dan $\mathrm{C}$ berbeda nyata $(\mathrm{P}<0.05)$ dibandingkan dengan kontrol (perlakuan A). Hasil ini menunjukkan bahwa pemberian $S$. platensis melalui pakan selama 40 hari pemeliharaan pada dosis 3\% (B) dan 6\% (C) dapat meningkatkan toleransi ikan terhadap stres yang ditimbulkan oleh tekanan lingkungan yaitu $\mathrm{pH}$ rendah. Menurut Adams et al. (2002) ketahanan ikan terhadap stress dapat dievaluasi mulai dari tingkat selular hingga individu dengan berbagai paparan stres diantaranya yaitu bahan kimia, salinitas, suhu, variasi $\mathrm{pH}$ serta paparan penyakit/patogen.

Dari hasil pengamatan penelitian, diketahui bahwa ikan zebra yang diberi paparan $\mathrm{pH}$ rendah mengalami stres yang ditunjukkan dengan perubahan tingkah laku ikan yaitu pergerakan ikan yang tidak seimbang, gerakan operkulum lebih cepat, warna memudar, dan ikan diam di dasar akuarium. Menurut Wendeelar (1997), upaya homeostasi ikan terhadap tekanan lingkungan berkaitan dengan regulasi glukosa darah dalam menurunkan stres sehingga ikan dapat beradaptasi dengan lingkungan. Glukosa akan dirombak menjadi energi sehingga kecukupan energi untuk meredam stres akan terpenuhi setelah glukosa dapat segera masuk ke jaringan ikan. Keberhasilan pasokan glukosa ini ditentukan oleh hormon insulin. Namun, pada saat terjadi stres kinerja hormon insulin terhambat akibat sekresi hormon kortisol sehingga glukosa akan sulit masuk ke dalam jaringan untuk meredam stres. Pada penelitian ini, ikan zebra yang diberi pakan suplementasi $S$. platensis lebih tahan terhadap stres $\mathrm{pH}$ rendah daripada perlakuan kontrol. Hal ini disebabkan karena $S$. platensis diketahui mampu bekerja meningkatkan sistem imun, mempertahankan homeostasis terhadap tekanan stres lingkungan, serta menghambat peningkatan kadar kortisol dalam darah. Kemampuan $S$. platensis menghadapi stres terkait dengan kandungan antioksidan 
diantaranya yaitu pikosianin, triterpenoid, serta karotenoid yang diperlukan dalam menghadapi stress (Arun et al., 2012).

\section{KESIMPULAN DAN SARAN}

\section{Kesimpulan}

Penambahan tepung Spirulina platensis berpengaruh nyata $(\mathrm{P}<0,05)$ terhadap pertumbuhan panjang mutlak, laju pertumbuhan spesifik panjang, pertumbuhan bobot mutlak, laju pertumbuhan spesifik bobot serta kelangsungan hidup ikan pasca paparan $\mathrm{pH}$ rendah. Perlakuan terbaik pada perlakuan $\mathrm{C}(6 \%)$ dengan nilai secara berurutan yaitu $0.646 \pm 0.112 \mathrm{~cm}$, $0.714 \pm 0.10 \%, \quad 0.102 \pm 0.020 \quad \mathrm{~g}$, $1.422 \pm 0.215 \%$, dan $63.33 \pm 5.77 \%$. Kelangsungan hidup ikan zebra setelah pemberian $S$. patensis melalui pakan selama 40 hari pemeliharaan yaitu $100 \pm 0 \%$ pada semua perlakuan.

\section{Saran}

Perlu dilakukan penelitian mengenai kombinasi S. platensis dan probiotik untuk meningkatkan kinerja pertumbuhan dan ketahanan tubuh ikan zebra terhadap tekanan lingkungan dan penyakit.

\section{DAFTAR PUSTAKA}

Abdelkhalek N.K., Ghazy E.W., AbdelDaim M.M. (2015). Pharmacodynamic Interaction of Spirulina platensis and Deltamethrin in Freshwater Fish Nile Tilapia, Oreochromis niloticus: Impact on Lipid Peroxidation and Oxidative Stress. Environ. Sci. Pollut. Res. Int., 22,3023-3031. doi: 10.1007/s11356.

Adams, S. M., Barton, B., \& MacKinley, D. (2002). Environmental Stress and Health in Fish. Canada: American Fisheries Society.

Arun, N., Gupta, S. and Singh, D.P. (2012). Antimicrobial and Antioxidant
Property of Commonly Found Microalgae Spirulina platensis, Nostoc Muscorum and Chlorella pyrenoidosa Against Some Pathogenic Bacteria and Fungi. Int. J. of Pharm. Sci. \& research, 3(12), 4866-4875.

Bahmai, A., Ghaeni. M., \& Roomiani, L. (2017). Evaluation of Growth and Survival of Zebra Fish, Danio rerio by Flake Food that Formulated with Spirulina . I. J. Aqua. Anim. Health, 3 (1), 82-89.

Dani, N.P., Budiharjo, A., \& Listyawati, S. (2005). Komposisi Pakan Buatan untuk Meningkatkan Pertumbuhan dan Kandungan Protein Ikan Tawes (Puntius javanicus Blkr.). Biosmart, 7(2), 83-90.

El-Sheekh, M., El-Shourbagy, I., Shalaby, S., \& Hosny, S. (2014). Effect of Feeding Arthrospira platensis (Spirulina) on Growth and Carcass Composition of Hybrid Red Tilapia (Oreochromis niloticus $\mathrm{x}$ Oreochromis mossambicus). Turkish Journal of Fisheries and Aquatic Sciences, $\quad 14, \quad 471-478$. http://doi.org/10.4194/1303-2712v14_2_18.

Kabata, Z. (1985). Parasites and Diseases Of Fish Cultured in The Tropics. London: Taylor and Prancis.

Karga, J dan Mandal, S. (2016), Effect of Different Feeds on the Growth, Survival and Reproductive Performance of Zebra Fish, Danio rerio (Hamilton, 1822). Aquacult Nutr, 23: 406413. https://doi.org/10.1111/anu.124 $\underline{07}$. 
Kim, S-S., Rahimnejad, S., Kim, K-W., \& Lee, K-J. (2013). Partial Replacement of Fish Meal with Spirulina pacifica in Diets for Parrot Fish (Oplegnathus fasciatus). Turkish Journal of Fish and Aquatic Sciences, 13, 197-204. doi: 10.4194/1303-2712-v132-01.

Kusumaningrum, G. A., Alamsjah, M. A. (2014). Uji Kadar Albumin dan Pertumbuhan Ikan Gabus (Channa striata) dengan Kadar Protein Pakan Komersial yang Berbeda. Jurnal Ilmiah Perikanan dan Kelautan, 6 (1), 25-29.

Nazhiroh, N., Mulyana, \& Mumpuni, F.S. (2019). Pengaruh Penambahan Tepung Spirulina platensis dalam Pakan terhadap Pertumbuhan dan Efisiensi Pakan Ikan Mas Koki (Carassius auratus). Jurnal Mina Sains 5 (1), 50-57.

Nur, M.M. A. (2014). Potensi Mikroalga sebagai Sumber Pangan Fungsional di Indonesia. Jurnal Eksergi, 11(2), 1 6.
Rowe, H.W., Withey J.H., Neely M.N. (2014). Zebrafish as a Model for Zoonotic Aquatic Pathogens. Developmental and Comparative Immunology. 46. 10.1016/j.dci.2014.02.014

Takeuchi, T., Lu, J., Yoshizaki, G., \& Satoh, S. (2002). Effect on the Growth and Body Composition of Juvenile Tilapia Oreochromis Niloticus Fed Raw Spirulina. Fisheries Science, 68(2), 34-40.

Wendelaar Bonga, S.E. 1997. The stress response in fish. Physiological Reviews, 77, 591-625

Virnanto, L.A., Rachmawati, D., \& Samidjan, I. (2016). Pemanfaatan Tepung Hasil Fermentasi Azolla (Azolla microphylla) sebagai Campuran Pakan Buatan untuk Meningkatkan Pertumbuhan dan Kelulushidupan Ikan Gurame (Osphronemus gouramy). Journal of Aquaculture Management and Technology, 5(1), 1-7. 